Research Article

\title{
Study on the Loess Immersion Test of Metro Line 2 in Xi'an, Shaanxi Province, China
}

\author{
Yuanjun Xu $\mathbb{D}$, Jiading Wang $(\mathbb{D}$, Tianfeng Gu $\mathbb{D}$, Dengfei Zhang $\mathbb{D}$, and Weiqian Ma $\mathbb{D}$ \\ State Key Laboratory of Continental Dynamics/Department of Geology, Northwest University, Xi'an 710069, Shaanxi, China \\ Correspondence should be addressed to Jiading Wang; wangiiading029@163.com
}

Received 2 December 2020; Revised 6 January 2021; Accepted 24 January 2021; Published 3 February 2021

Academic Editor: Song-He Wang

Copyright (C) 2021 Yuanjun Xu et al. This is an open access article distributed under the Creative Commons Attribution License, which permits unrestricted use, distribution, and reproduction in any medium, provided the original work is properly cited.

\begin{abstract}
With the implementation of China's western development and "One Belt, One Road" initiative, there are more and more projects in the collapsibility loess area, and the collapsibility loess problem encountered in the construction is becoming more and more prominent. In this paper, the collapsibility loess of the south extension section of Xi'an Metro Line 2 is investigated, and its collapsibility characteristics are studied through a large-scale site immersion test. The test site was a $15 \mathrm{~m}$ diameter circular test pit, which took 35 days for water injection and 60 days for observation after water stopped. The test results showed that the maximum self-weight collapsibility of the soil layer in the test pit is $32 \mathrm{~mm}$, and the deformation amount is $10.05 \mathrm{~mm}$ in $Q_{3}$ and $9.55 \mathrm{~mm}$ in $Q_{2}$. The maximum deformation amount of $32 \mathrm{~mm}$ is less than $70 \mathrm{~mm}$ in the shallow marker; it may be caused by the paleosol layer as a bridge to provide a support to the overlying soil layer. The shape of the sphere of influence after immersion resembles a trumpet, slightly protruding outwards from the paleosol. The scope of influence between the infiltrated and saturated zones gradually increases with depth, and the saturated zone is generally smaller than the infiltrated zone. The research results of this paper can provide technical support and reference for the construction of Xi'an Metro Line 2 and other related projects in the region.
\end{abstract}

\section{Introduction}

With the implementation of China's western development and the "One Belt, One Road" initiative, there are more and more projects in collapsible loess area, and the problems encountered in the construction of collapsible loess are becoming more and more tough. When collapsible loess is wetted by water, the internal structure of the loess is destroyed under the joint action of self-weight stress or selfweight stress and external additional stress, and the strength of the loess decreases significantly [1-3]. When the remaining strength between loess units is insufficient to resist their stresses, the soil structure is rapidly disrupted, resulting in significant self-weight collapsible deformation of the soil [4-6].

At present, there are two methods to study loess collapsibility: one is the combination of indoor test and mathematical method, and the other is the field water immersion test. The former is mainly to study the mechanism and mathematical model of loess subsidence [7-11], while the latter can intuitively get the test site after immersion subsidence development process and water migration process in space [12-17], and then the site of the subsidence level to make evaluation [18-23], and this method is more recognized by the engineering practice. Xing and Liu [24] analyzed the influencing factors of negative skin friction for pile foundations in collapsible loess regions through water immersion tests, and the main factors are cumulative relative collapse amount, pile type, and change in loess collapsibility. Liu et al. [25] proposed a conceptual microstructural model of a four-tiered hierarchy to represent soil's structural characteristics and to account for its high collapsibility. Wang et al. [26-28] studied the water permeability of collapsible soils and new empirical equations for the water permeability in terms of suction or degree of saturation. The field immersion test method can get the true collapsible coefficient of the test site, which is also recognized as a more reliable method of collapsible evaluation [29-34], but 
because of its high engineering costs, labor, and time, it is carried out relatively little.

In this paper, we conducted a large-scale in situ water immersion test, where the Xi' an Metro Line 2 is located, and studied the water immersion characteristics of the loess by observing the changes of water content and subsidence in different depths of loess layers, and then the self-weight collapsibility could be obtained to evaluate the collapsibility of loess site. This field immersion test is of great practical value for the theoretical study of loess collapsibility in the Loess Plateau and for the construction of the subway project in this area.

\section{Geological Background}

2.1. Overview of the Test Site. Metro Line 2 of Xi' an is high in the middle and low at the north and south, with an average slope drop of $2-5 \%$, and the slope drop is larger in some areas of loess depression. The loess immersion test site is located at the southeast corner of the intersection of Shenhe Third Road and Changning Road, between Hejiaying Station and Changning Station of the subway line, covering an area of $110 \mathrm{~m} \times 85 \mathrm{~m}$, about $100 \mathrm{~m}$ away from the subway line. And the test site is flat; the specific location of the test site is shown in Figure 1.

2.2. Soil Layers. The southern extension of Metro Line 2 of $\mathrm{Xi}$ 'an crosses the primary and secondary terraces of the river and the Shenhe loess plateau, and collapsible loess is mainly found in the area from No. 3 waterworks Plant in Xi' an Chang'an District to Shenhe loess plateau. The soil layers of the site from top to bottom are as follows (Figure 2). The top soil layer is $4 \mathrm{~m}$ thick plain fill $\left(Q_{4}{ }^{\mathrm{ml}}\right)$, which is yellow-brown, loose, highly compressible soil, and mainly treated loess soil, with a small amount of tile locally. And the upper part has about $0.30 \mathrm{~m}$ of asphalt concrete pavement. The next soil layer is $3.3-8.6 \mathrm{~m}$ thick wind-deposited new loess $\left(Q_{3}{ }^{\mathrm{eol}}\right)$, which is yellow-brown, microporous, containing small amounts of snail fragments and calcareous mycelium, and continuously distributed on the surface of loess plateau. Furthermore, this soil layer is collapsible and hard to hard plastic above the water table. The third soil layer is $3-7.9 \mathrm{~m}$ thick eluvial paleosol $\left(Q_{3}{ }^{\mathrm{el}}\right)$, which is reddish brown, dominated by clay particles, and containing a large number of calcareous mycelium and nodules, with developed macropores. And this soil layer has slight collapsibility with a continuous distribution in the loess zone. The fourth soil layer is $0.6-8.9 \mathrm{~m}$ thick aeolian old loess $\left(Q_{2}{ }^{\mathrm{eol}}\right)$, which is yellowish brown, with needle-like pores, containing small number of calcareous nodules and scattered snail shells, and in a predominantly hard plastic state, locally plastic. The layer is continuously distributed in this region and is interlayered with the eluvial paleosol layer. The last layer is 0.6-4.2 $\mathrm{m}$ thick eluvial paleosol $\left(Q_{2}{ }^{\mathrm{el}}\right)$, which is brown-red, with needle-like pores, agglomerate structure, locally nodule-rich, and mainly in a plastic state. This layer is continuously distributed in this region and interlayered with aeolian old loess.
The thickness of the collapsibility loess of the test site is $14.4 \mathrm{~m}$, and the stratigraphic characteristics of the test site were consistent with the stratigraphy of the Shenhe loess plateau (collapsibility loess area), where the Metro Line 2 passes through. Therefore, the stratigraphic characteristics of the loess immersion test site are representative of the stratigraphy of the Metro Line 2's collapsibility loess area.

2.3. Test Site Representation. In the southeast of the immersion test pit, five trial pits were dug artificially at a depth of $32 \mathrm{~m}$, and the undisturbed loess samples were taken from the wall of the wells along the depth per meter for testing the indoor physical and mechanical indexes. And the single-line method was used for the loess collapsibility, $200 \mathrm{kPa}$ was taken within $10.0 \mathrm{~m}$ of the test pressure, and the saturated dead weight pressure of the overlying soil was taken from $10.0 \mathrm{~m}$ below to the top surface of the nonwet sagging loess, but $300 \mathrm{kPa}$ was taken when the pressure exceeded $300 \mathrm{kPa}$. The indoor test results show that the self-weighted collapsibility depth is about $30.4 \mathrm{~m}$, and the self-weighted collapsibility coefficient $\left(\delta_{z}\right)$ is between 0.002 and 0.050 , and the collapsibility coefficient $\left(\delta_{s}\right)$ is between 0.010 and 0.053 . Thus, it can be seen that the depth of self-weighted collapsibility depth is deeper, the self-weighted collapsibility and the collapsibility amount are relatively larger, and the degree of collapsibility is more intense in the south extension section of Metro Line 2. The immersion site was chosen as a representative test site.

\section{Test Procedure}

3.1. Test Pit Design and Survey Point Layout. According to the geotechnical conditions of the exploratory wells of test site, the depth of self-weighted collapsibility of the site is about $30 \mathrm{~m}$. The test pit is circular, $30 \mathrm{~m}$ in diameter, and $50 \mathrm{~cm}$ in depth, and the bottom of the test pit was covered with $10 \mathrm{~cm}$ of sand gravel. A total of 46 shallow markers and 28 deep markers were laid out (Figure 3), while three reference points and two observation reference points were set up in the test site for the water immersion test to meet the collapsibility observation.

Take the center of the test pit as the origin and arrange three survey lines radially in three directions to the edge of the pit, and the angle of the three lines is $120^{\circ}$ (Table 1). Each survey line arranged 7 shallow markers inside the test pit, 8 shallow markers outside the pit, and 1 in the center of the test pit (Figure 3). The shallow marker was made of galvanized steel pipe and $25 \mathrm{~mm}$ in diameter. The markers inside the test pit were $2.5 \mathrm{~m}$ in length, those outside the test pit were $2.0 \mathrm{~m}$ in length, and the round steel plate is $15 \mathrm{~cm}$ in diameter and $0.3 \mathrm{~cm}$ thick at the base (Figure 4 ). The shallow pit at the base of the shallow markers was excavated by hand to a depth of $50 \mathrm{~cm}$, with the surface layer of floating soil and cultivated soil removed, and tamped by light tapping.

Take the center of the test pit as the origin, and set survey lines I, II and III of the shallow marker on both sides at an angle of $30^{\circ}$ as deep marker survey lines. There were six survey lines in total (Figure 3), and each survey line was $15 \mathrm{~m}$ 


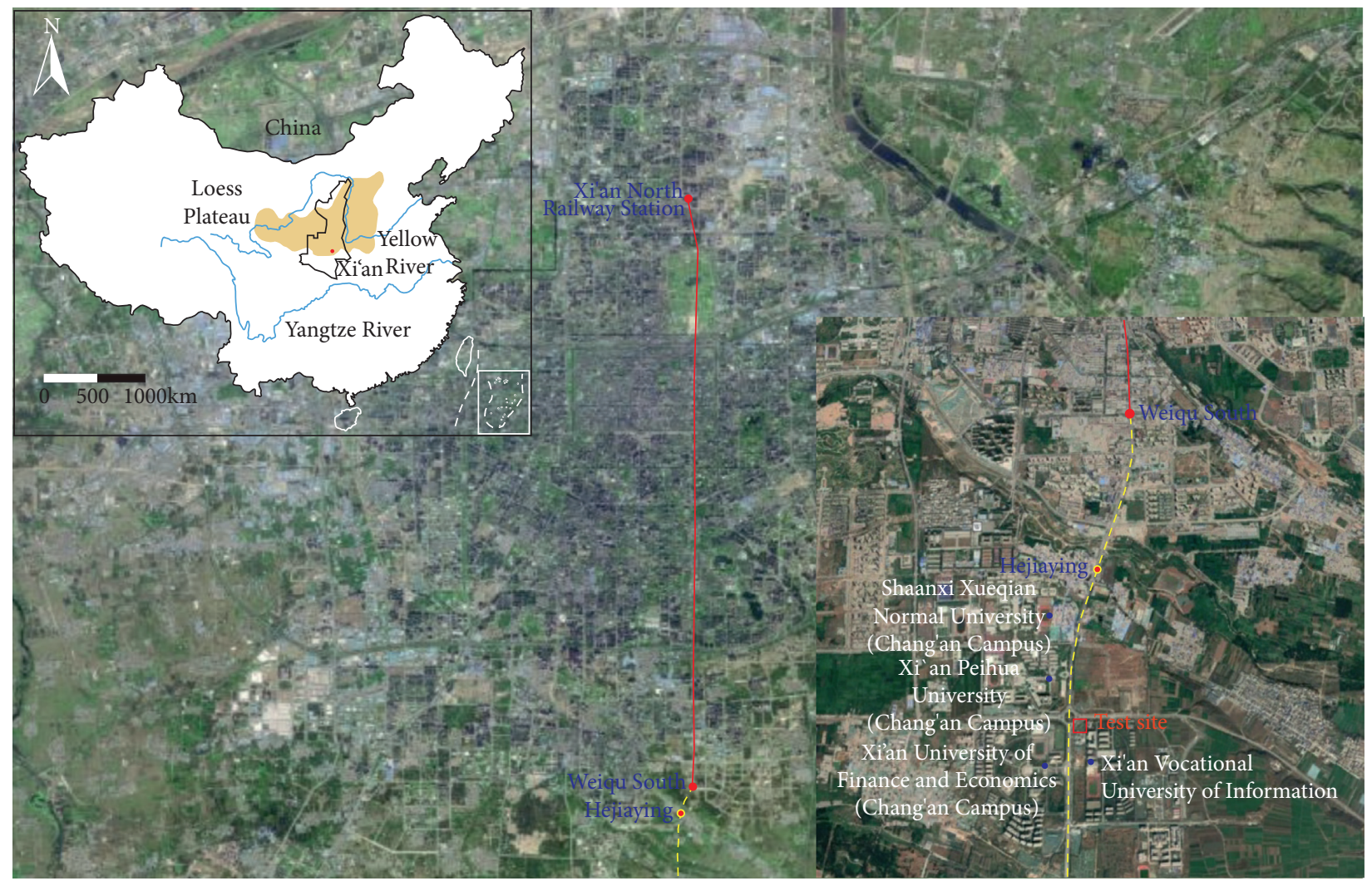

- Metro Line 2

Metro Line under construction

- Metro Station

- Metro Station under construction

Figure 1: Location of the immersion test site (the map is according to "Xi'an Urban Rail Transit Phase III Construction Plan (2019-2024)," https://www.xianrail.com/\#/planConstruction/linesPlanning).

in length (Table 1). A total of 28 deep markers were laid out in the 6 survey lines, and there were 5 deep markers for survey lines IV, V, VII and IX, while 4 deep markers for survey lines VI and VIII. There were 3 groups of 6 deep markers in the new loess layer, with depths of $4.0 \mathrm{~m}, 6.5 \mathrm{~m}$, and $9.4 \mathrm{~m}$, and 2 deep markers in each depth (the same below). And there was 1 group of 2 deep markers in the paleosol layer, with a depth of $12.4 \mathrm{~m}$, and 4 groups of 8 deep markers in the old loess layer, with depths of $14.0 \mathrm{~m}, 16.0 \mathrm{~m}$, $18.0 \mathrm{~m}$, and $20.0 \mathrm{~m}$, respectively. Then, there were 6 groups of 6 deep markers in the interbedding layers of paleosol layer and old loess layer, with depths of $22.5 \mathrm{~m}, 23.5 \mathrm{~m}, 24.5 \mathrm{~m}$, $28.0 \mathrm{~m}, 30.5 \mathrm{~m}$, and $33.0 \mathrm{~m}$. The deep marker (Figure 4) consisted of several mechanically connected galvanized pipes and a $60 \mathrm{~mm}$ diameter iron base plate welded vertically. And the location of the subbase reflects the subsidence of the soil beneath it. There is a fixed steel ruler on the exposed part of the pole for subsidence observation. The minimum scale of the steel ruler was $1.0 \mathrm{~mm}$, and a PVC pipe was set outside of the marker to ensure that the subsidence plate can settle freely without the influence of soil friction, and the PVC pipe is exposed to the ground about $1 \mathrm{~m}$, and the gap between the external PVC pipe and the buried hole was backfilled with medium coarse sand, so that the deep marker also played an objective role in strengthening water infiltration.

In this immersion test, in order to accelerate the soil saturation of the site, six water infiltration holes were placed in the test pit, and the holes were evenly distributed on the circle of $7 \mathrm{~m}$ from the center of the test pit. The specific location of the infiltration holes is shown in Figure 3. These infiltration holes were drilled and filled with medium coarse sand to promote water infiltration.

There were 4 exploratory wells (T1-T4) in the test pit to install moisture sensor, and the exploratory wells were $16 \mathrm{~m}, 18 \mathrm{~m}, 21 \mathrm{~m}$, and $25 \mathrm{~m}$ away from the pit center (Figure 3). 19 soil moisture sensors (Figure 4) were installed in the exploratory wells (Table 2). The exploratory wells were excavated in advance, and the soil moisture sensors were buried in the side walls of the exploratory wells at a predetermined depth, and after the sensors worked normally, the exploratory wells were backfilled and tamped by layering. The moisture sensor is connected to the current acquisition card and transmits the signal wirelessly via data transfer unit (DTU) for real-time wireless transmission of moisture data. 


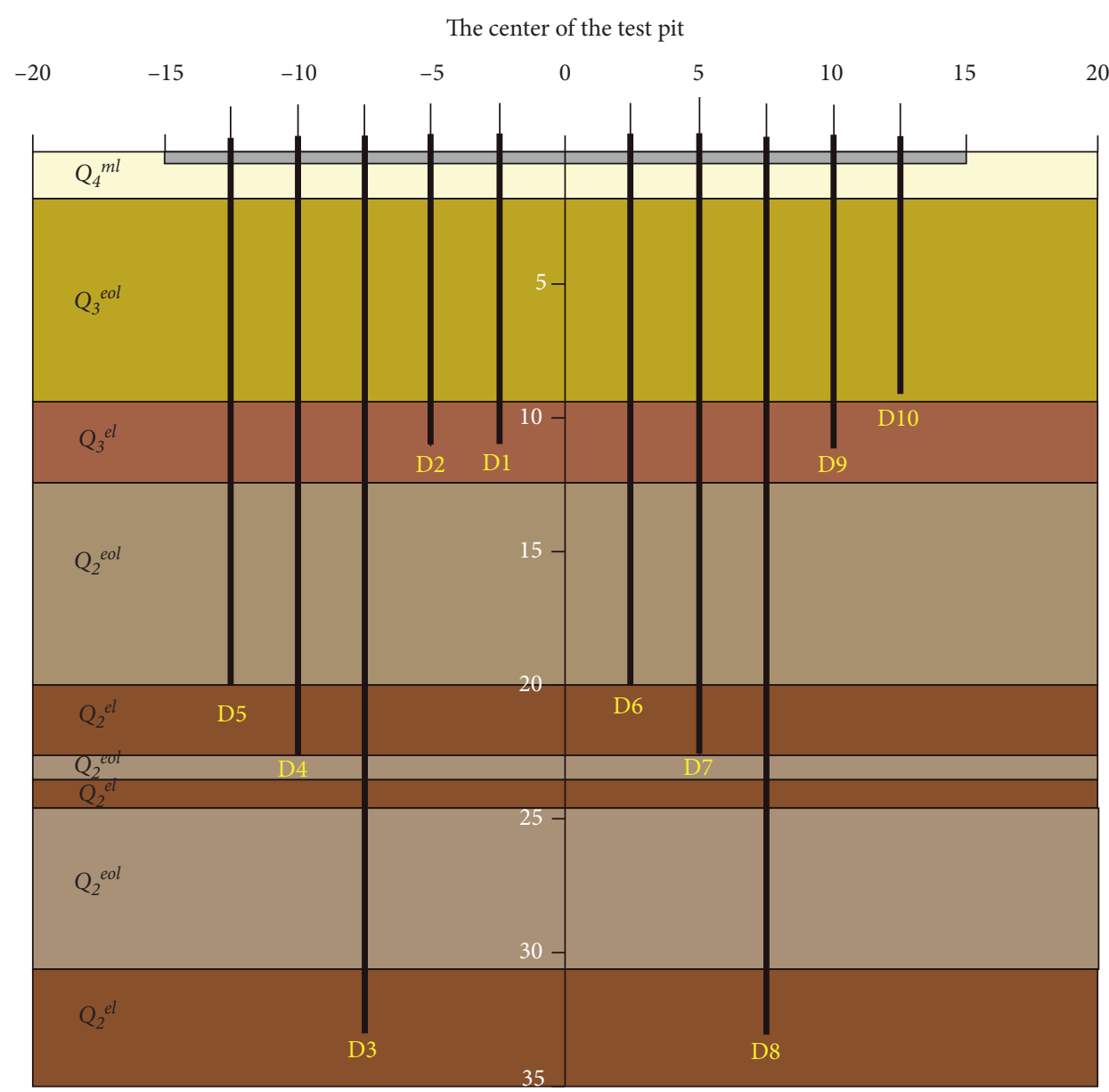

FIGURE 2: Geological profile of the test site (survey lines IV and V).

3.2. Water Injection Process. During the test, water injection was done through pump to keep the water level of the test pit maintained at around $40 \mathrm{~cm}$. A ruler is set at the edge of the test pit to record the pit head, which is always kept at $40 \mathrm{~cm}$ during the water injection process. The test pit was injected for 35 days from July 13 to August 17, 2017, with a water injection of $13,255 \mathrm{~m}^{3}$ and an average daily water injection of $378.7 \mathrm{~m}^{3}$. The relation between single-day water injection and cumulative water injection is shown in Figure 5. As can be seen from Figure 5, the water injection was large in the early stage, with an average daily water injection of $390.4 \mathrm{~m}^{3} /$ $\mathrm{d}$ in the first 23 days. Since then, the water injection started to decrease, and the average daily water injection was stable at $353.4 \mathrm{~m}^{3} / \mathrm{d}$.

The test was terminated when the average collapsibility in the last 5 days was less than $1 \mathrm{~mm} / \mathrm{d}$. The average collapsibility in the last 5 days before the water stop was nearly zero, less than $1 \mathrm{~mm} / \mathrm{d}$, for 35 days of water injection, which met the water stop standard. After water stopped, the test was continued for 15 day, and the average collapsibility was less than $1 \mathrm{~mm} / \mathrm{d}$ for 5 day, which met the termination conditions. No excessive evaporation or precipitation occurred during the injection period, and the evaporation and rainfall had a negligible effect of less than $1 \%$ on the immersion test.

\section{Results and Analysis}

\subsection{Variation of Soil Moisture Content}

4.1.1. Immersion Process. The data collected by the moisture sensor in this large in situ immersion test is the volumetric moisture content of the soil, and then it can be converted to soil saturation. The soil saturation curve at each moisture sensor was plotted (Figure 6).

The distance between the edge of the test pit and exploratory well $\mathrm{T} 1$ is $1 \mathrm{~m}$. Soil moisture sensors are buried to a depth of $4.2 \mathrm{~m}, 11 \mathrm{~m}, 16 \mathrm{~m}, 21 \mathrm{~m}, 24 \mathrm{~m}$, and $26 \mathrm{~m}$. As shown in Figure 6(a), it can be seen that the $11 \mathrm{~m}, 24 \mathrm{~m}$, and $26 \mathrm{~m}$ sensors first detected moisture content changes on day 2 , followed by the $16 \mathrm{~m}$ and $21 \mathrm{~m}$ sensors in the middle-buried depths on days 3 and 5. That is to say, the shallow and deep sensors detected moisture changes earlier than the middle sensors. In terms of time, when the soil layer reached saturation, $11 \mathrm{~m}$ and $24 \mathrm{~m}$ soil reached saturation first on days 4 and 3, respectively. And then $26 \mathrm{~m}, 21 \mathrm{~m}$, and $16 \mathrm{~m}$ soil also reached saturation on days 15,16 , and 26 , respectively. The moisture sensors in exploratory well $\mathrm{T} 2$ were saturated with several days of soil moisture content growth after detecting moisture content changes. 


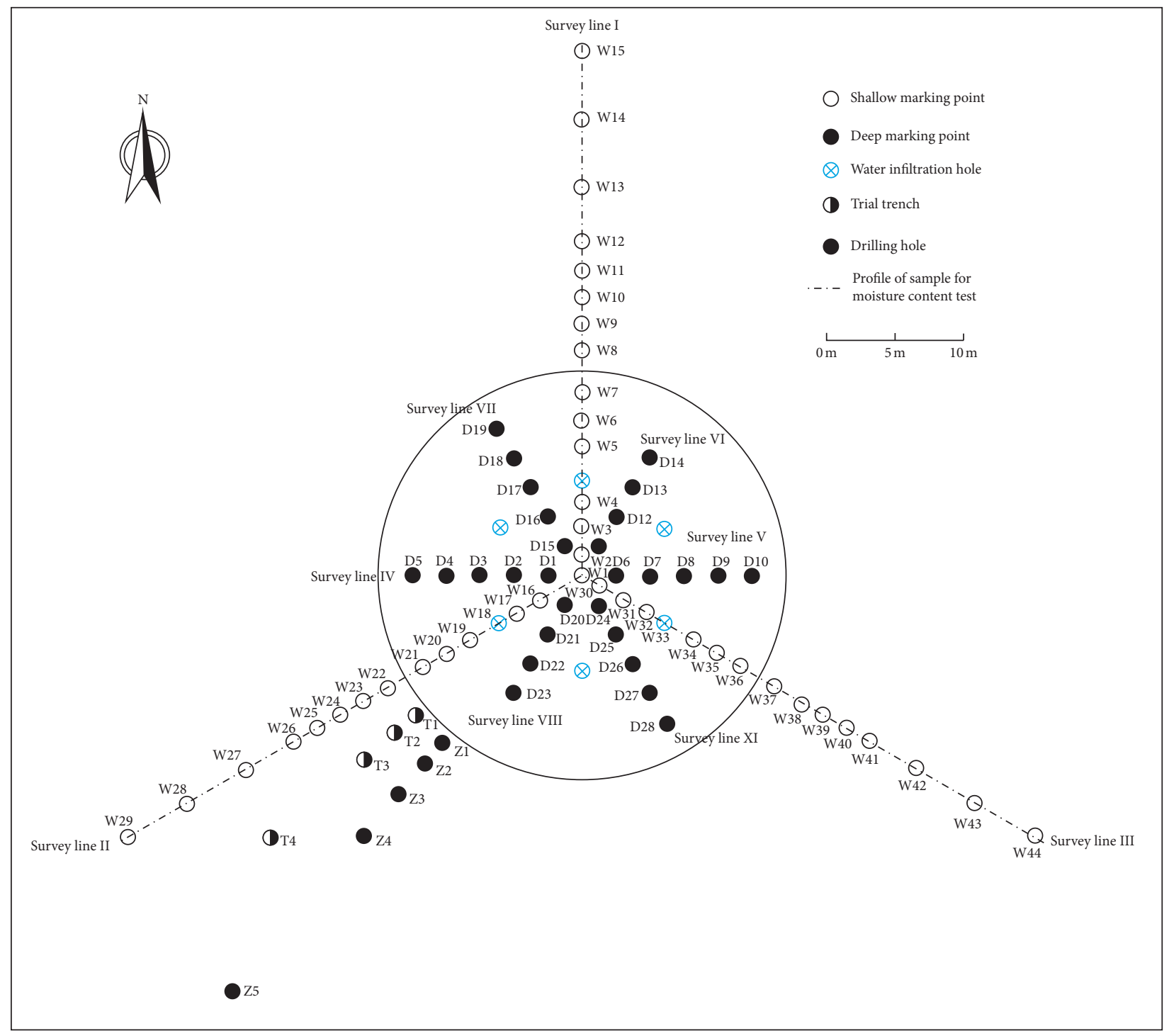

Figure 3: The layout of water immersion test.

The distance between the edge of the test pit and exploratory well T2 is $3 \mathrm{~m}$. Soil moisture sensors are buried to a depth of $16 \mathrm{~m}, 21 \mathrm{~m}, 24 \mathrm{~m}, 26 \mathrm{~m}$, and $30 \mathrm{~m}$. From Figure 6(b), it can be reflected that the pattern of moisture change in exploratory well T2 is similar to that in exploratory well T1, and the moisture sensor in the deep part of the exploratory well detects the moisture content change earlier. On the third day, after the start of the water injection, the moisture sensor at $30 \mathrm{~m}$ in exploratory well $\mathrm{T} 2$ detected the moisture change; after that, the volumetric moisture content of the soil rapidly increased to saturation and finally stabilized at saturation. On the 11th day, after the start of the water injection, the moisture sensor at $26 \mathrm{~m}$ showed an increase in the moisture content. On the 15th day, after the start of the water injection, the moisture sensor at $24 \mathrm{~m}$ also showed an increase in the moisture content. In contrast to the three moisture sensors at depth, the moisture sensors at $16 \mathrm{~m}$ and $21 \mathrm{~m}$ did not go through a rapid upward phase after detecting moisture changes, but rather they developed slowly, indicating that the position was near the immersion line.

The distance between the edge of the test pit and exploratory well T3 is $6 \mathrm{~m}$. Soil moisture sensors are buried to a depth of $16 \mathrm{~m}, 21 \mathrm{~m}, 24 \mathrm{~m}, 26 \mathrm{~m}$, and $30 \mathrm{~m}$. As seen in Figure $6(\mathrm{c})$, the pattern of water movement in exploratory well $\mathrm{T} 3$ is the same as in exploratory well T2. In exploratory well $\mathrm{T} 3$, the moisture sensor at $30 \mathrm{~m}$ detected the change in water content on the 6th day after the start of water injection. And the moisture sensors at $26 \mathrm{~m}$ and $24 \mathrm{~m}$ detected the change in water content on the 16th and 21st days, respectively.

The distance between the edge of the test pit and exploratory well T4 is $10 \mathrm{~m}$. Soil moisture sensors are buried to a depth of $21 \mathrm{~m}$ and $30 \mathrm{~m}$. As shown in Figure 6(d), because exploratory well T4 is far away from the immersion test pit, the volumetric moisture content of the soil layer at $21 \mathrm{~m}$ was 
TABLE 1: Marker properties.

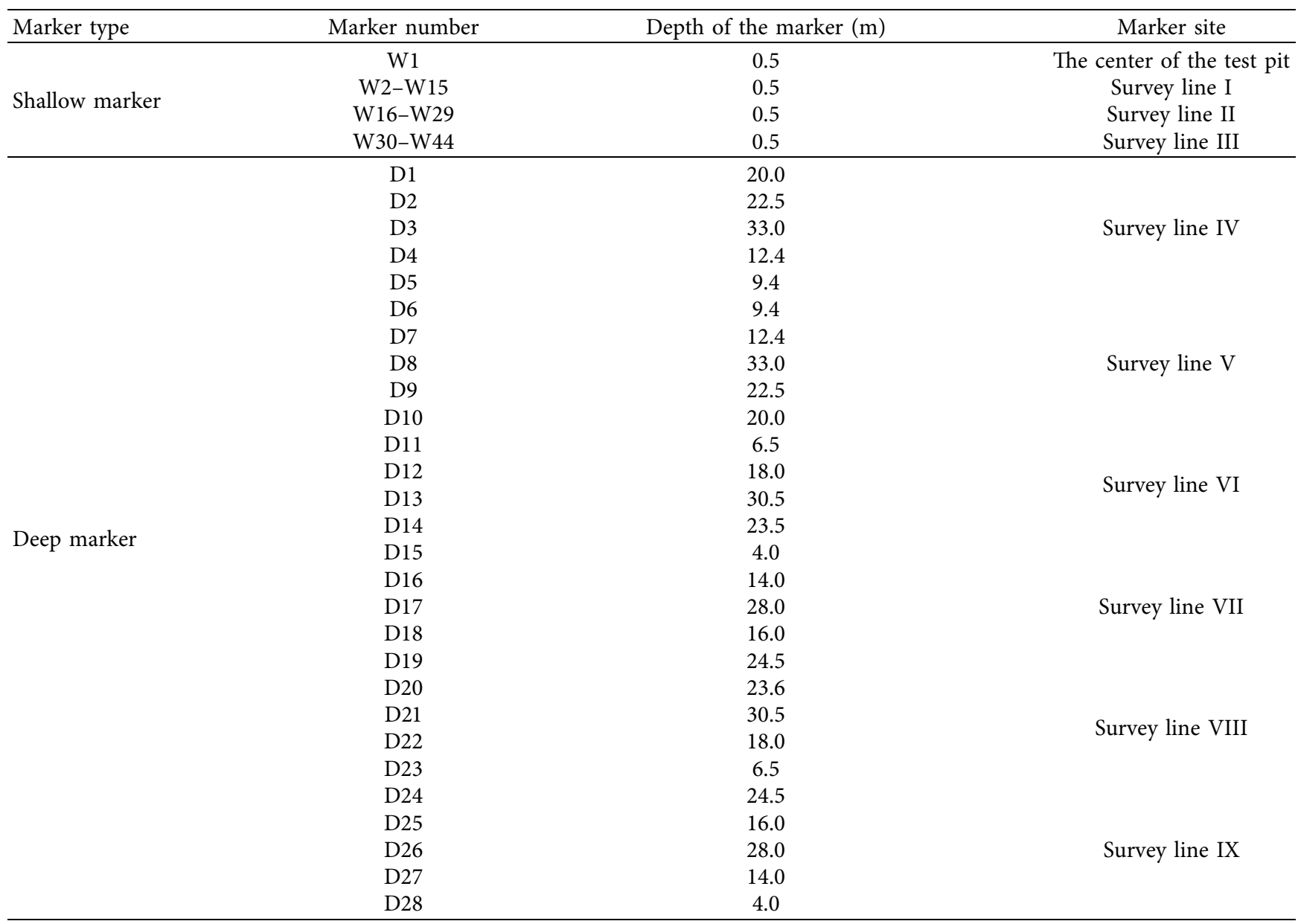

unaffected by the immersion test, except for the moisture sensor at the bottom $30 \mathrm{~m}$, which was saturated rapidly with water after the moisture change detected on the 9th day.

The scopes of immersion area and saturated area of immersion test can be obtained from previous monitoring data. As shown in Figure 7, the saturation range of the water after immersion resembles an inverted funnel, and the saturation range increases outwards in loess compared to old soils, because of the better permeability of loess than that of old soil. The influence of water at a depth of $30 \mathrm{~m}$ in the test pit is about $25 \mathrm{~m}$ from the edge of the pit, and the steepness of the infiltration line has been a matter of debate in the academic circles [35-41], as it tends to be slower for coarsegrained soils such as sandy soils and steeper for dense soils such as loess, clay, and old soils, because their vertical permeability coefficients are much higher than the horizontal permeability coefficients. The site's old soils have many layers and thicknesses, so they exhibit significantly larger vertical permeability coefficients, and for this reason, the steeper curve of the infiltration line at this site is normal.

4.1.2. Backwater Process. The field immersion test was stopped on August $17^{\text {th }}, 2017$, and observations continued for 53 days after stopping water injection. The backwater process and saturation changes of the test pit were completely documented.

In exploratory well T1 (Figure 8(a)), the saturation dropped most rapidly at $11 \mathrm{~m}$, which was from $100 \%$ to $78 \%$ between the 7 th and 15th days after stopping water injection. There was a rapid loss of water after stopping water injection due to the fluid water around the water sensor during the water immersion period. And the soil at $21 \mathrm{~m}$ and $24 \mathrm{~m}$ remained saturated. The saturation of soil at $16 \mathrm{~m}, 26 \mathrm{~m}$, and $30 \mathrm{~m}$ in exploratory well T3 started to decrease on the 5th, 4 th, and 22nd days after stopping water injection, respectively (Figure $8(\mathrm{~b})$ ). But the saturation of the soil at $21 \mathrm{~m}$ and $24 \mathrm{~m}$ in exploratory well T3 started to increase on the 15th day after stopping water injection and finally reached saturation on the $22 \mathrm{nd}$ day. The saturation of the soil at $30 \mathrm{~m}$ in exploratory well T4 started to decrease on the 22nd day after stopping water injection and was stabilized on the 43rd day (Figure 8(c)). However, the soil at $21 \mathrm{~m}$ is still not saturated. The $21 \mathrm{~m}$ and $24 \mathrm{~m}$ parts of the test site are interlayers of old loess and paleosol, and we can see that the depth of the test site is an interlayer of old loess and paleosol by comparing exploratory well $\mathrm{T} 1$, exploratory well $\mathrm{T} 3$, and exploratory well T4 (Figure 8). This means that water continues to permeate out of the pit after the water stops, and the water loss is faster in other layers, but the water loss is slower in this 


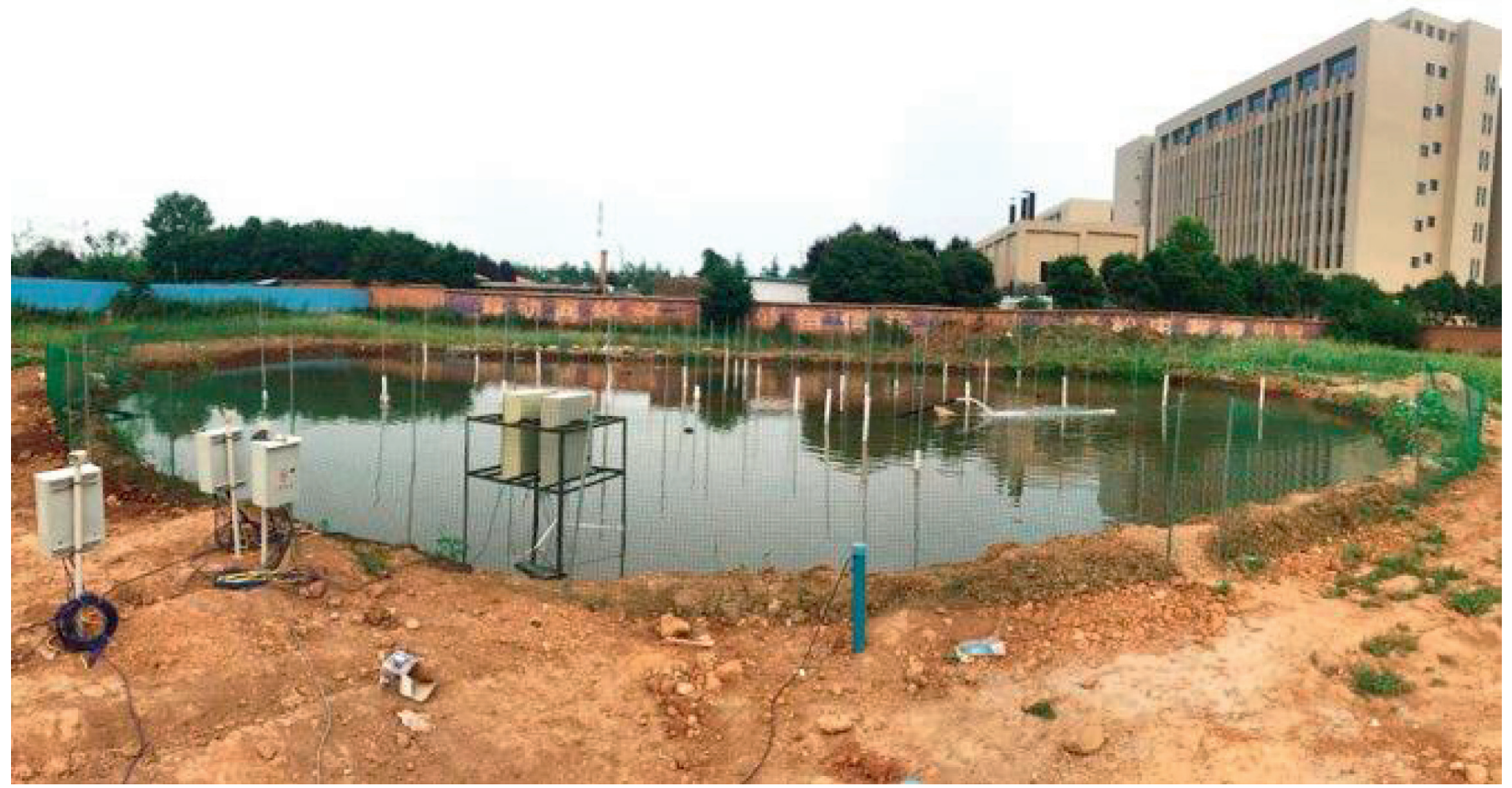

(a)

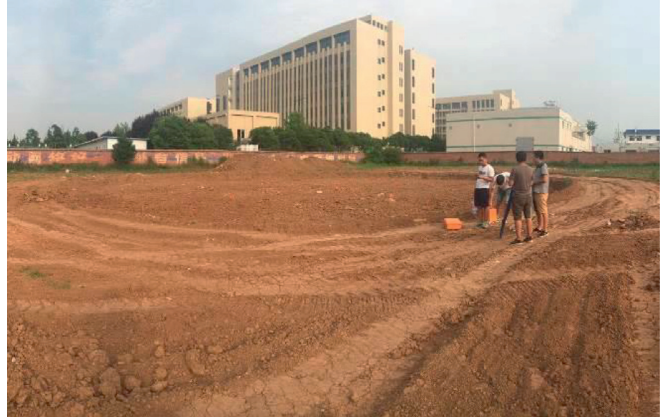

(b)

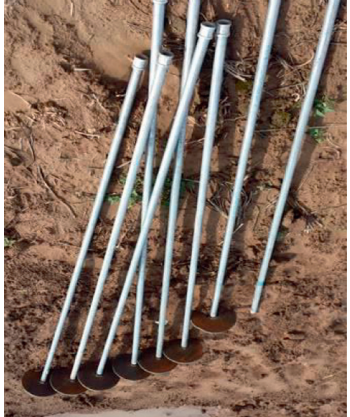

(c)

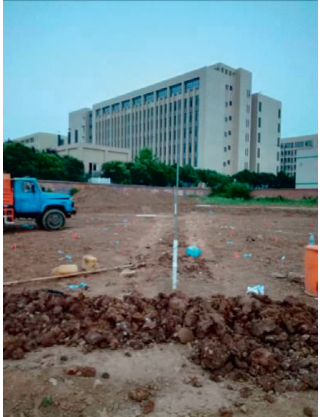

(d)

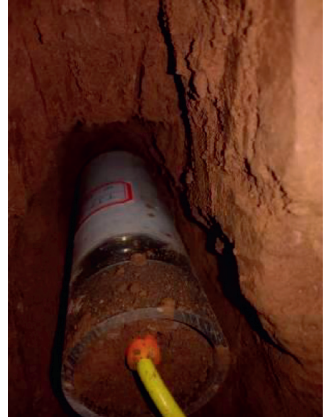

(e)

FIgure 4: Site photos. (a) Overall view of the test pit. (b) Site leveling. (c) Shallow markers. (d) Deep markers. (e) Installation of the soil moisture sensor.

TABLE 2: Layout of soil moisture sensors.

\begin{tabular}{lccr}
\hline Soil layer & The number of soil moisture sensors & Position $(\mathrm{m})$ & Exploratory wells \\
\hline New loess $Q_{3}{ }^{\text {el }}$ & 1 & 4.0 & $\mathrm{~T} 1$ \\
Paleosol $Q_{3}{ }^{\mathrm{el}}$ & 1 & 11.0 & $\mathrm{~T} 1$ \\
Old loess $Q_{2}{ }^{\text {eol }}$ & 3 & 16.0 & $\mathrm{~T} 1, \mathrm{~T} 2, \mathrm{~T} 3$ \\
Paleosol $Q_{2}{ }^{\mathrm{el}}$ & 4 & 21.0 & $\mathrm{~T} 1, \mathrm{~T} 2, \mathrm{~T} 3, \mathrm{~T} 4$ \\
Paleosol $Q_{2}{ }^{\mathrm{el}}$ & 3 & 24.0 & $\mathrm{~T} 1, \mathrm{~T} 2, \mathrm{~T} 3$ \\
Old loess $Q_{2}{ }^{\text {eol }}$ & 3 & 26.0 & $\mathrm{~T} 1, \mathrm{~T} 2, \mathrm{~T} 3$ \\
Old loess $Q_{2}{ }^{\text {el }}$ & 4 & 30.0 & $\mathrm{~T} 1, \mathrm{~T} 2, \mathrm{~T} 3, \mathrm{~T} 4$ \\
\hline
\end{tabular}

interlayer due to the relative water insulation of the upper and lower paleosols, and it saturates the farther layers through lateral permeation. The longest water infiltration distance between the $21 \mathrm{~m}$ and $24 \mathrm{~m}$ interbedded layers of old loess and old soil was $6 \mathrm{~m}$.
4.2. Analysis of Surface Subsidence and Deformation. This test was observed in a total of 95 days, water injection lasted 35 days, and after stopping water injection, observation continued, and the subsidence was stable after 44 days of observation. The variation of each shallow markers in survey 


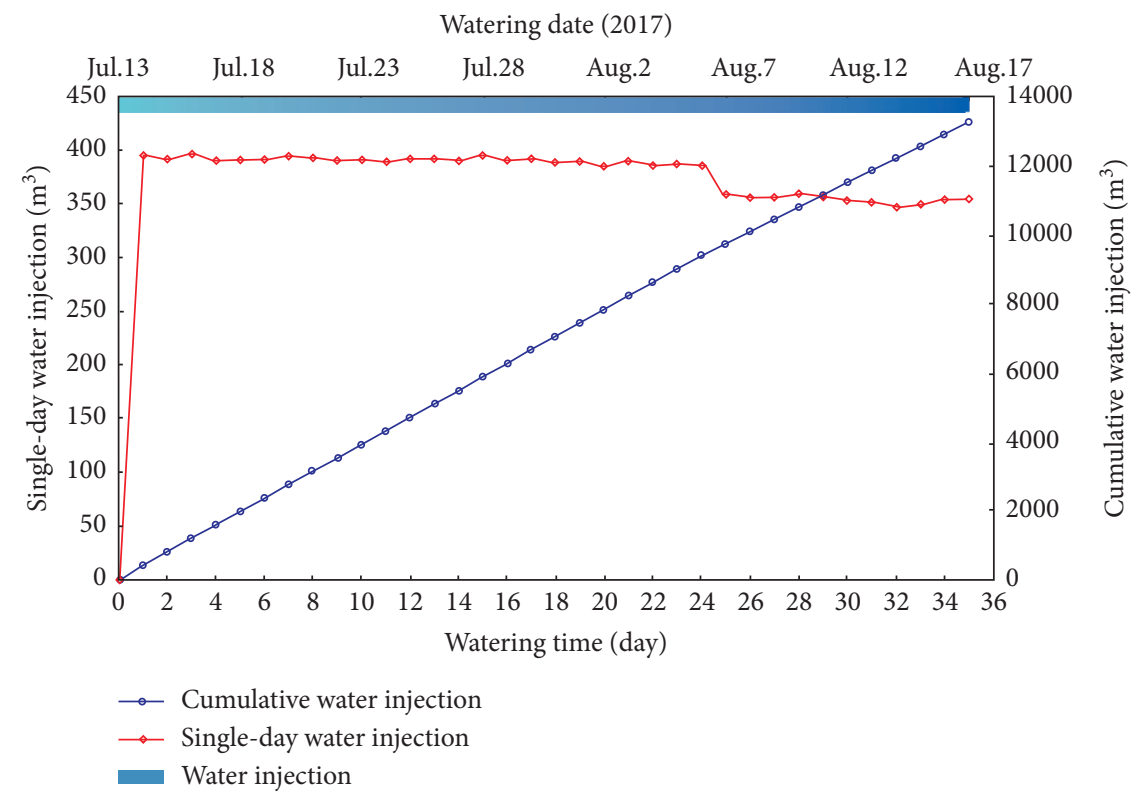

FIGURE 5: The relation between single-day water injection and cumulative water injection.

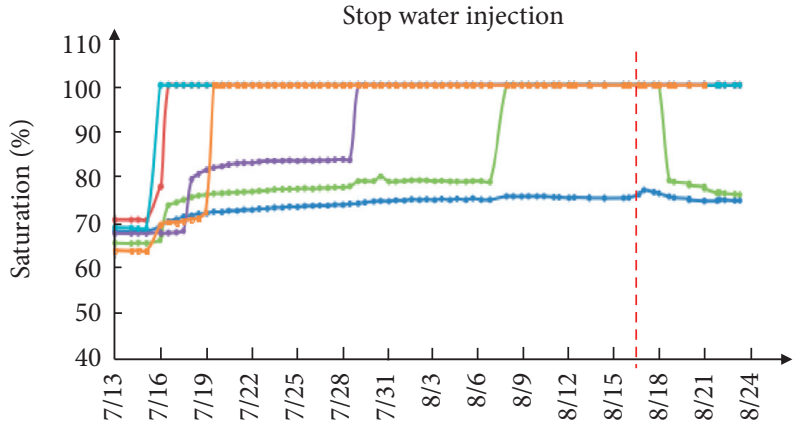

Immersion date

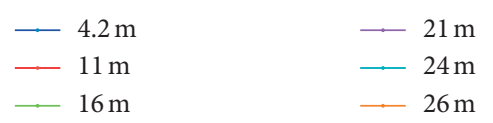

(a)
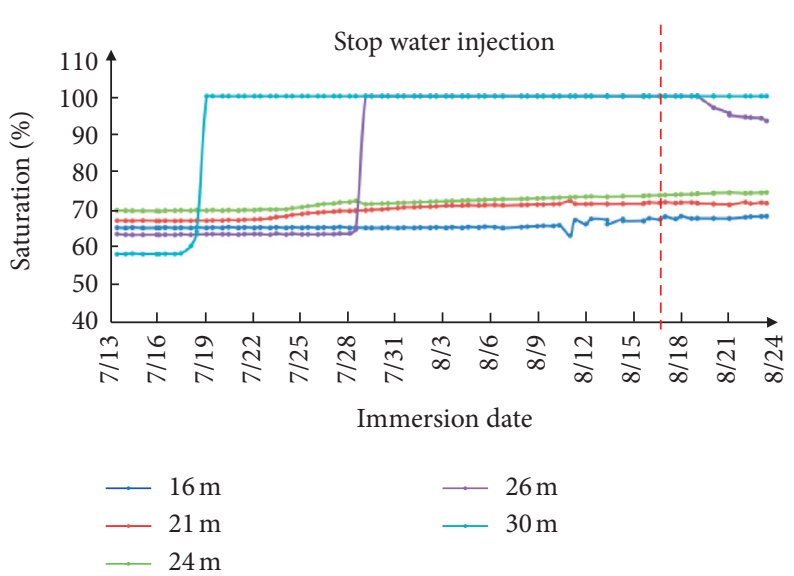

(c)

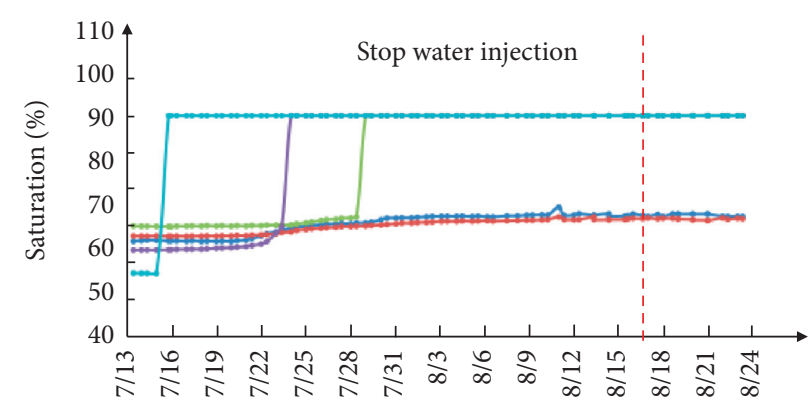

Immersion date
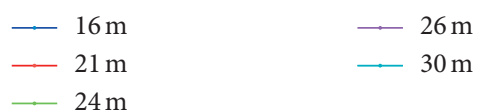$$
-30 \mathrm{~m}
$$

(b)

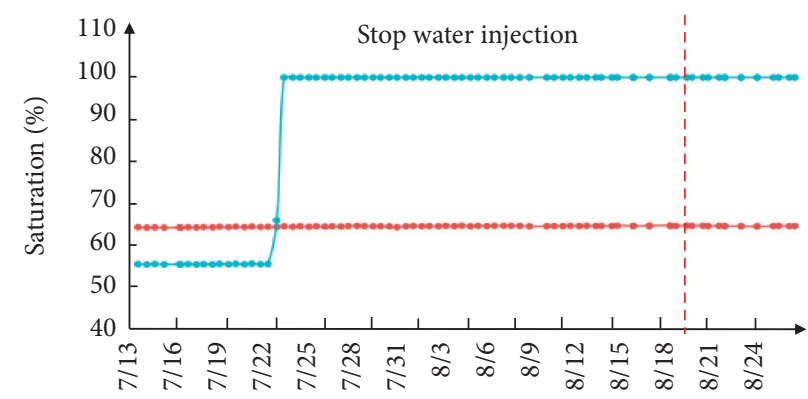

Immersion date

$-21 \mathrm{~m}$

$-30 \mathrm{~m}$

(d)

Figure 6: The soil saturation curve with immersion time: (a) exploratory well T1, (b) exploratory well T2, (c) exploratory well T3, and (d) exploratory well T5. 


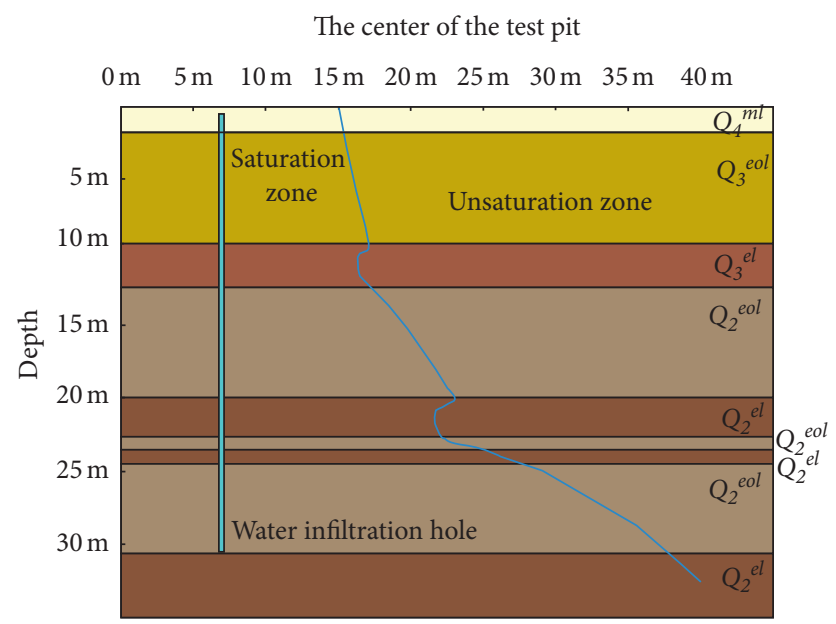

FIGURE 7: The scopes of the immersion area and saturated area of immersion test.
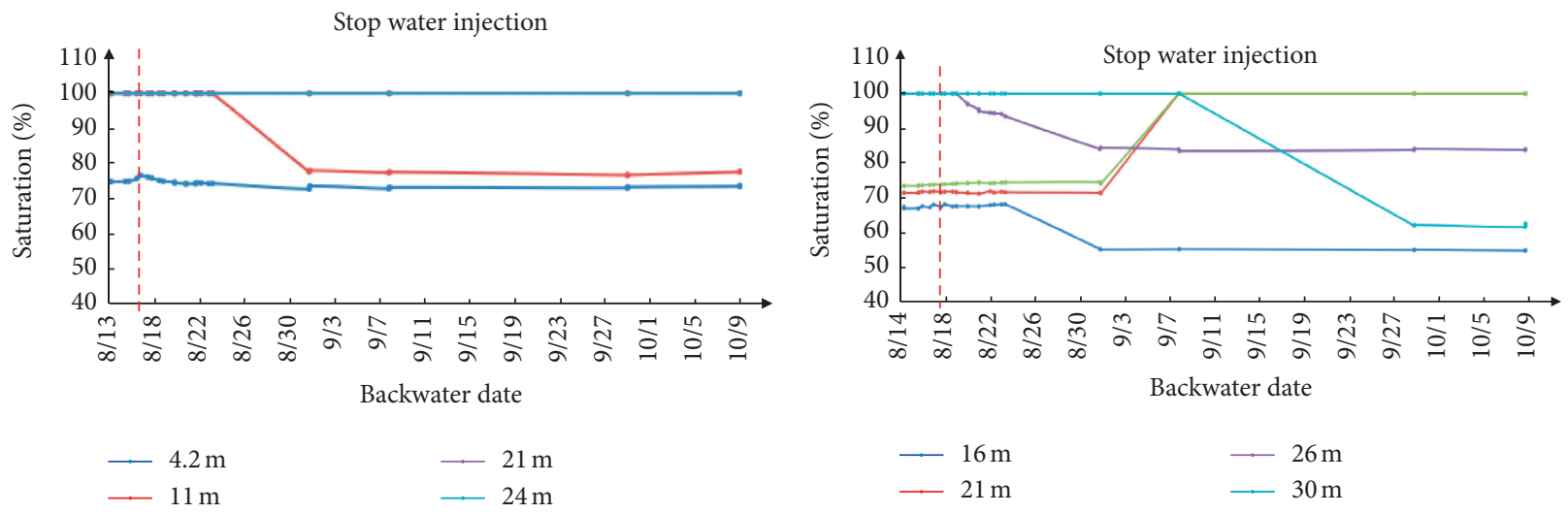

(a)

$-24 \mathrm{~m}$

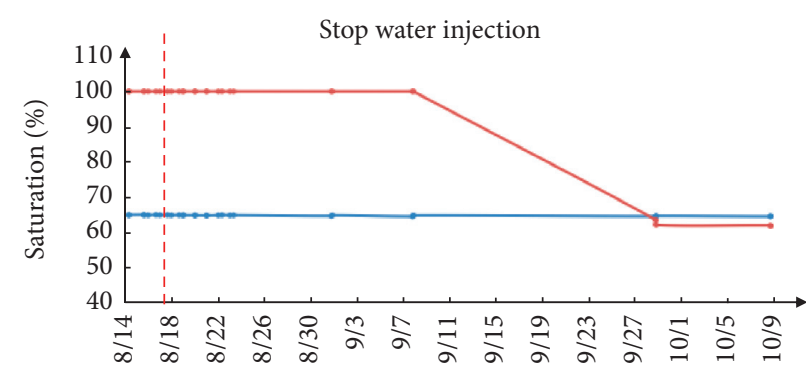

Backwater date

(c)

Figure 8: The soil saturation curve with backwater time: (a) exploratory well T1, (b) exploratory well T3, and (c) exploratory well T5.

lines I and II is small during the water immersion and stopping water injection periods. The deformation of each markers was $1 \sim 3 \mathrm{~mm}$ during the water immersion period, and the maximum settlement was less than $4 \mathrm{~mm}$, but compared with the subsidence variation of each shallow marker in survey lines I and II, the subsidence variation of six shallow markers (W31-W36) inside the survey line III inside test pit was larger, and the maximum subsidence was $31.4 \mathrm{~mm}$. As shown in Figure 9, the subsidence curves of survey line III can be divided into five stages.

(1) Phase one is the initial stage (0 day-2 days). In the early stage of immersion, the soil surface was unsaturated, and water rapidly filled the soil pores and 
Observation time (day)

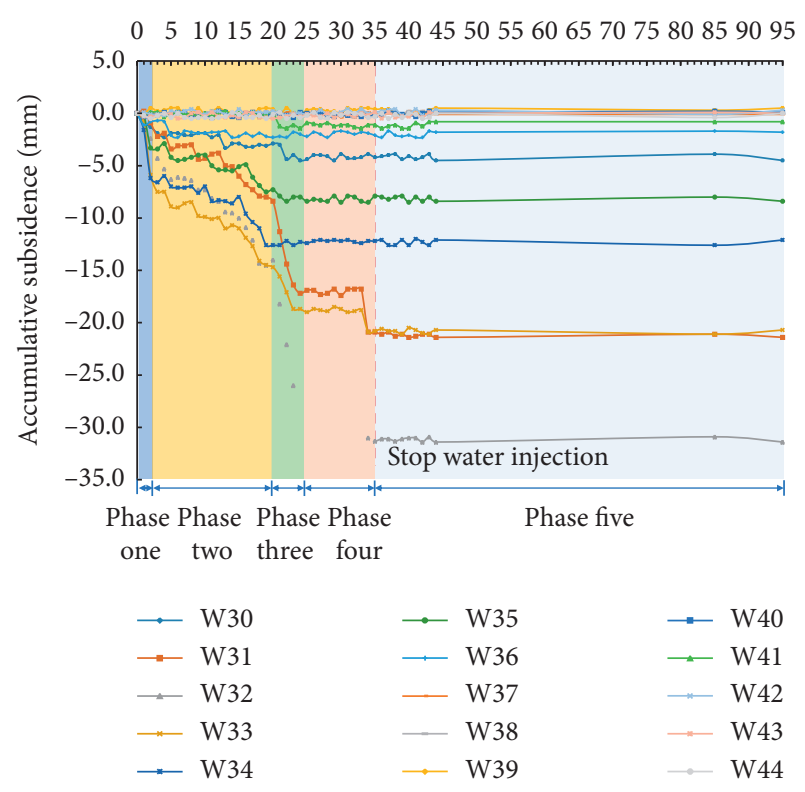

FIgURE 9: Typical accumulative surface subsidence curves (shallow markers of survey line III).

infiltrated. Because there was a water infiltration hole between shallow marker W32 and W34 (it was like an artificially large fissure), large amounts of water infiltrated through the hole, and then it caused small subsidence at nearby monitoring points, while other monitoring points had no subsidence.

(2) Phase two is the deformation stage (2 days-20 days). During this stage, the soil surface inside the test pit was saturated, but outside the test pit it was still unsaturated. As the water continued to infiltrate, the soil on both sides of the water infiltration hole was falling down by the force of erosion and water flow, and the water infiltration hole was gradually increasing, resulting in an obvious increase in subsidence nearby, and the subsidence of other shallow markers in the test pit away from the water infiltration hole was also slowly increasing due to the loess wetting deformation and collapsibility. But the subsidence of shallow markers outside the test pit was still near zero, because the vertical infiltration coefficient of loess is significantly larger than the horizontal infiltration coefficient, and the soil surface outside the test pit was not saturated for a short time.

(3) Phase three is the rapid deformation stage (20 days-24 days). In this stage, the subsidence of shallow markers nearby the water infiltration hole had a sharp increase. This should be due to the continuous erosion of the water flow, which had led to the expansion of the water infiltration hole, and then the soil at the nearby shallow marker had been eroded causing rapid subsidence. Subsidence also continued to increase at shallow markers in the test pit away from the water infiltration hole. As the immersion time increased, the shallow markers outside the test pits near the test pits also showed significant subsidence, indicating that the soil surface had become saturated.

(4) Phase four is the stability stage (24 days-35 days). During this stage, the seepage was stable, the infiltration velocity decreased, and the subsidence and deformation of soil were stable. But subsidence of shallow markers nearby the water infiltration hole rose, the saturation of the loess layer is higher, and the interstitial pore fills a large amount of free liquid water, the water level remained almost constant during this time, the pore water pressure decreases, and the effective stress of the soil increases, resulting in consolidation subsidence.

(5) Phase five is the stability stage (35 days-95 days). At this stage, after stopping water injection, the subsidence and deformation of soil also had smaller consolidation subsidence. Over time, however, the soil surface reached a new equilibrium, and the amount of subsidence is stabilized.

In the immersion test, the subsidence of each survey line was uneven, and the surface subsidence and deformation mainly occurred at the three shallow markers of survey line III (W31, W32, and W33), and almost no subsidence occurred at the shallow marker in the center of the test pit (Figure 10). In order to investigate the cause of uneven subsidence at the test pit, two hand-holes were placed in each of the three survey lines after the test, and the hand-holes were made by Luoyang shovel to check for stratigraphic differences at the site. The comparison of stratigraphy reveals no stratigraphic differences at the test site. But the outlet of the water diversion pipe in this test was located in the middle of the shallow markers W30 and W31, which is related to water head erosion. This may be the main reason for the largest subsidence of shallow markers W31, W32, and W33.

\subsection{Analysis of Layered Subsidence and Deformation.} According to the previous investigation data, the depth of subsidence of self-weight wet collapse is $30 \mathrm{~m}$, so the monitoring depth range of this test is from $0 \mathrm{~m}$ to $33 \mathrm{~m}$. Figure 11 shows the accumulative surface subsidence curve of deep markers with different immersion days. As shown in Figure 11, the collapsibility deformation of deep markers with buried depths $6.5,22.5$, and $23.5 \mathrm{~m}$ is larger, and the collapsibility deformation is $-10 \mathrm{~mm},-8.55 \mathrm{~mm}$, and $-8.85 \mathrm{~mm}$, respectively. The collapsibility deformation of the rest of the deep markers is less than $2 \mathrm{~mm}$. So, collapsibility deformation of deep markers in this immersion test is smaller. It may be related to the water infiltration holes; water infiltration holes and deep marker accelerate the water infiltration and make the deeper soil layer saturate earlier, and then the deeper soil layers result in wetting and deformation, but the middle layers are not saturated with water yet, so that making it difficult to reach the normal overlying pressure of the saturated layer. 


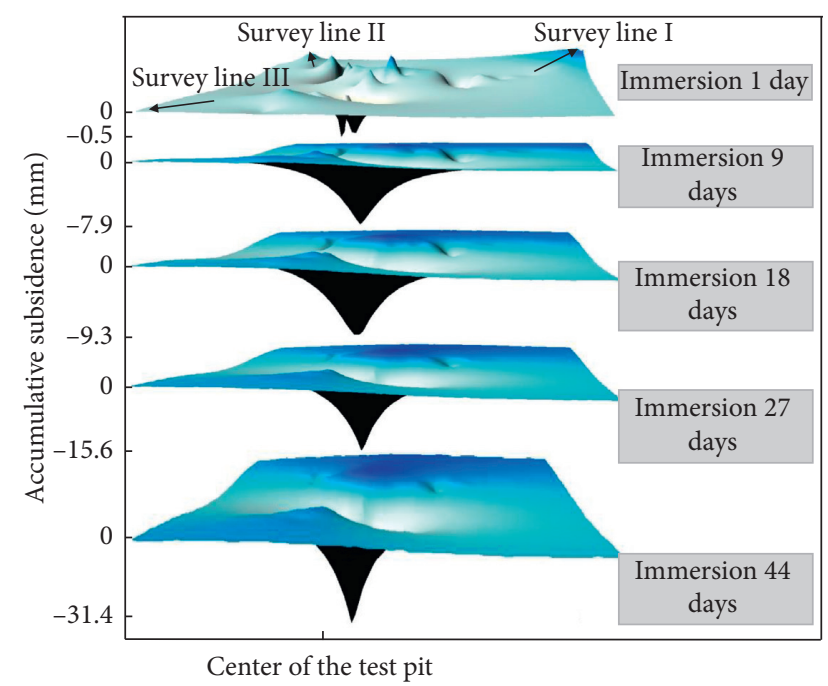

FIgURE 10: Accumulative surface subsidence curve of different immersion days.

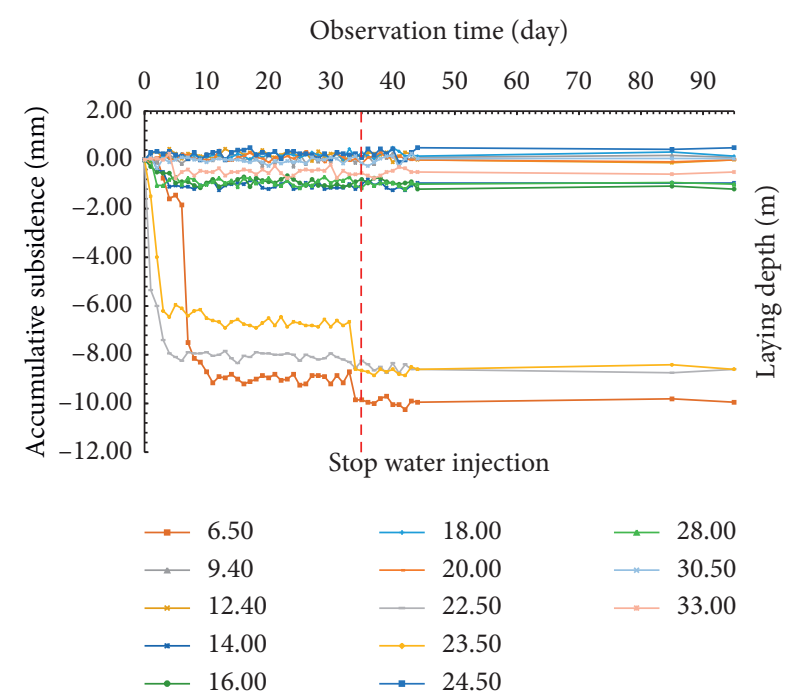

Figure 11: Accumulative surface subsidence curve of deep markers with different immersion days.

\section{Discussion}

5.1. Pattern of Deep Soil Subsidence. When wet loess is wetted by water, the internal structure of the soil is damaged by the joint action of self-weight stress or self-weight stress and external additional stress, and its strength is obviously reduced. When the remaining strength between loess units is not enough to resist its stress, the soil structure is rapidly damaged, thus causing significant self-weight wetting deformation of the soil body.

In this immersion test, the deep soil subsidence does not satisfy the sum of the upper stratigraphic subsidence equal to the lower stratigraphic subsidence. The subsidence of each layer at depth can be calculated by using the difference between the upper marker (sensor reading) and the deformation of the lower marker (sensor reading), as shown in Table 3.

It can be seen from Table 3 that, in this water immersion test, some deep layers showed a rise instead of a fall, which is not in line with the general common sense. Then, paleosol layers in th water immersion test site are mainly distributed in 9.4-12.4 $\mathrm{m}$ and $20-24 \mathrm{~m}$, and it is aquiclude and has stronger mechanical strength compared with the Q3 loess by analyzing the exploratory well data. This water immersion test pit has thicker paleosol layer. After the test pit is soaked in water, under the promotion of water infiltration holes and deep markers, the water infiltrates from top to bottom and quickly enters the deep layers in the test pit through the water infiltration holes and deep markers at the same time. Because the loess layer has better permeability than the paleosol layer, during the water infiltration process, the loess layer first reaches saturation, and collapsibility deformation occurs, while the paleosol soil layer is less permeable because its mechanical strength is better than that of the loess layer, so it has not yet deformed and provides support to the upper soil layer, which reduces the deformation of the upper soil layer and does not produce the collapsibility deformation equal to the sum of the lower soil layer. The paleosol soil layer is like a bridge to provide a support to the overlying soil layer. The deformation of the paleosol soil layer is corrected to $0 \mathrm{~mm}$, and the corrected deformation of each soil layer is obtained (Table 4 ).

5.2. The Recommended Values for Correction Factors of Collapsibility in This Region. Table 5 shows the collapsibility data for each shallow marker in the test pit and the average self-weight collapsibility of shallow markers inside the test pit in the immersion test.

Considering the effects of stratigraphic sedimentary age effects (mainly divided into $Q_{3}$ loess and $Q_{2}$ loess), the ratio $\beta_{0}^{\prime}$ is the measured self-weight collapsibility to the calculated value of self-weight collapsibility (not multiplied by $\beta_{0}$ ) according to

$$
\beta_{0}^{\prime}=\frac{\Delta_{z s}}{\sum_{i=1}^{n} \delta_{z s i} h_{i}} .
$$

In this formula, $\delta_{z s i}$ is the coefficient of self-weight collapsibility of $i$ soil layer, $\beta_{0}^{\prime}$ is the region-specific correction factors, $\Delta_{z s}$ is the measured self-weight collapsibility, and $h_{i}$ is the thickness of $i$ soil layer.

In order to obtain accurate regional correction factors, the appropriateness of backcalculating the maximum, minimum, and weighted average self-weight collapsibility is discussed. If the maximum measured self-weight collapsibility is chosen $\left(\Delta_{z s}=-31.4 \mathrm{~mm}\right)$, the result is 0.16 . If the minimum measured self-weight collapsibility is chosen $\left(\Delta_{z s}=0.2 \mathrm{~mm}\right)$, the result is 0 . If the weighted average measured self-weight collapsibility is chosen $\left(\Delta_{z s}=-0.51 \mathrm{~mm}\right)$, the result is 0.03 . It is recommended that $\Delta_{z s}=-31.4 \mathrm{~mm}$, and the regional correction factor is 0.16 to ensure project safety. 
TABLE 3: Calculation table of deep subsidence of deep markers.

\begin{tabular}{lcccc}
\hline Soil layer & Depth of the marker $(\mathrm{m})$ & Deformation of the marker $(\mathrm{mm})$ & Depth of the soil layer $(\mathrm{m})$ & Deformation of the soil layer $(\mathrm{mm})$ \\
\hline \multirow{2}{*}{ New loess } & 6.50 & -9.95 & $6.5-9.4$ & -10.05 \\
& 9.40 & 0.1 & $9.4-12.4$ & 0.1 \\
\hline Paleosol & 12.40 & 0 & $12.4-14$ & 0.95 \\
\hline \multirow{3}{*}{ Old loess } & 14.00 & -0.95 & $14-16$ & 0.25 \\
& 16.00 & -1.2 & $16-18$ & -1.35 \\
& 18.00 & 0.15 & $18-20$ & 0.15 \\
\hline Paleosol & 20.00 & 0 & $20-22.5$ & 8.6 \\
\hline Old loess & 22.50 & -8.6 & $22.5-23.5$ & 0 \\
\hline Paleosol & 23.50 & -8.6 & $23.5-24.5$ & -9.1 \\
\hline \multirow{2}{*}{ Old loess } & 24.50 & 0.5 & $24.5-28$ & 1.5 \\
\hline Paleosol & 28.00 & -1 & $28-30.5$ & -1.05 \\
\hline
\end{tabular}

Negative for subsidence; positive for elevation.

TABLE 4: Calculation table of deep subsidence of deep markers after correction.

\begin{tabular}{lcccc}
\hline Soil layer & Depth of the marker $(\mathrm{m})$ & Deformation of the marker $(\mathrm{mm})$ & Depth of the soil layer $(\mathrm{m})$ & Deformation of the soil layer $(\mathrm{mm})$ \\
\hline \multirow{2}{*}{ New loess } & 6.50 & -9.95 & $6.5-9.4$ & -10.05 \\
& 9.40 & 0.1 & $9.4-12.4$ & 0.1 \\
\hline Paleosol & 12.40 & 0 & $12.4-14$ & 0 \\
\hline \multirow{2}{*}{ Old loess } & 14.00 & -0.95 & $14-16$ & -1.25 \\
& 16.00 & -1.2 & $16-18$ & 0.15 \\
& 18.00 & 0.15 & $20-22.5$ & 0 \\
\hline Paleosol & 20.00 & 0 & $22.5-23.5$ & 0 \\
\hline Old loess & 22.50 & -8.6 & $23.5-24.5$ & -9.1 \\
\hline Paleosol & 23.50 & -8.6 & $24.5-28$ & 1.5 \\
\hline \multirow{2}{*}{ Old loess } & 28.00 & 0.5 & $28-30.5$ & -1.05 \\
\hline Paleosol & 30.50 & -1 & $30.5-33$ & 0.55 \\
\hline
\end{tabular}

Negative for subsidence; positive for elevation.

TABLE 5: Self-weight collapsibility of shallow markers inside the test pit.

\begin{tabular}{lcccc}
\hline Survey line & Maximum of collapsibility $(\mathrm{mm})$ & $\begin{array}{c}\text { Minimum of } \\
\text { collapsibility }(\mathrm{mm})\end{array}$ & $\begin{array}{c}\text { Average of } \\
\text { collapsibility }(\mathrm{mm})\end{array}$ & $\begin{array}{c}\text { Average of collapsibility of shallow } \\
\text { markers inside the test pit }(\mathrm{mm})\end{array}$ \\
\hline Survey line I & -3.5 & 0.4 & -0.5 & -5.1 \\
Survey line II & -2.8 & 0.2 & -0.51 & -14.33 \\
Survey line III & -31.4 & -4.5 & & -53 \\
\hline
\end{tabular}

Negative for subsidence; positive for elevation.

\section{Conclusions}

The following conclusions are obtained from this field immersion test of collapsibility loess and its indoor test results.

The maximum self-weight collapsibility of the soil layer in the test pit is $32 \mathrm{~mm}$, and the deformation amount is $10.05 \mathrm{~mm}$ in $Q_{3}$ and $9.55 \mathrm{~mm}$ in $Q_{2}$. The maximum deformation amount of $32 \mathrm{~mm}$ is less than $70 \mathrm{~mm}$ in the shallow marker, and the test site is judged to be a non-self-weight collapsibility loess site. According to the principles of site selection and the comprehensive analysis of the investigation data near Metro Line 2, the field immersion test represents the line range of the southern extension of Metro Line 2 at Shenhe loess.

The loess layer has better permeability than the paleosol layer. During the water infiltration process, the loess layer first reaches saturation, and collapsibility deformation occurs, while the paleosol soil layer is less permeable because its mechanical strength is better than that of the loess layer, so it has not yet deformed and provides support to the upper soil layer, which reduces the deformation of the upper soil layer and does not produce the collapsibility deformation equal to the sum of the lower soil layer. The paleosol soil 
layer is like a bridge to provide support to the overlying soil layer.

In order to obtain accurate regional correction factors, the appropriateness of backcalculating the maximum, minimum, and weighted average self-weight collapsibility is discussed. It is recommended that $\Delta_{z s}=-31.4 \mathrm{~mm}$, and the regional correction factor is 0.16 to ensure project safety.

\section{Data Availability}

All the data included in this study are available from the corresponding author upon request.

\section{Conflicts of Interest}

The authors declare that they have no conflicts of interest.

\section{Acknowledgments}

The research presented in this paper was funded by the State Key Program of the National Natural Science Foundation of China (Grant nos. 41630639 and 41372329), the National Natural Science Foundation of China (Grant no. 41941017), and the Special-Funded Program on National Key Scientific Instruments and Equipment Development (Grant no. 42027806).

\section{References}

[1] Z. J. Xu, Z. G. Lin, and M. S. Zhang, "Loess in China and loess landslides," Chinese Journal of Rock Mechanics, vol. 26, no. 7, pp. 1297-1312, 2007.

[2] J. G. Gong, Y. W. Jia, Z. H. Zhou, Y. Wang, W. L. Wang, and H. Peng, "An experimental study on dynamic processes of ephemeral gully erosion in loess landscapes," Geomorphology, vol. 125, no. 1, pp. 203-213, 2011.

[3] S.-J. Feng, F.-L. Du, Z.-M. Shi, W.-H. Shui, and K. Tan, "Field study on the reinforcement of collapsible loess using dynamic compaction," Engineering Geology, vol. 185, pp. 105-115, 2015.

[4] M. Momeni, A. Shafiee, M. Heidari, M. K. Jafari, and M. R. Mahdavifar, "Evaluation of soil collapse potential in regional scale," Natural Hazards, vol. 64, no. 1, pp. 459-479, 2012.

[5] Z.-Z. Qian, X.-L. Lu, W.-Z. Yang, and Q. Cui, "Behaviour of micropiles in collapsible loess under tension or compression load," Geomechanics and Engineering, vol. 7, no. 5, pp. 477-493, 2014.

[6] L. Wang, J. Sun, X. Huang et al., "A field testing study on negative skin friction along piles induced by seismic subsidence of loess," Soil Dynamics and Earthquake Engineering, vol. 31, no. 1, pp. 45-58, 2011.

[7] Z. C. Wang, Y. L. Xie, J. L. Qiu, Y. W. Zhang, and H. B. Fan, "Field experiment on soaking characteristics of collapsible loess," Advances in Materials Science and Engineering, vol. 2017, Article ID 6213871, 17 pages, 2017.

[8] E. Derbyshire, T. A. Dijkstra, I. J. Smalley, and Y. Li, "Failure mechanisms in loess and the effects of moisture content changes on remoulded strength," Quaternary International, vol. 24, pp. 5-15, C, 1994.

[9] Y. M. Reznik, "Influence of physical properties on deformation characteristics of collapsible soils," Engineering Geology, vol. 92, no. 1-2, pp. 27-37, 2007.
[10] M. Jiang, H. Hu, and F. Liu, "Summary of collapsible behaviour of artificially structured loess in oedometer and triaxial wetting tests," Canadian Geotechnical Journal, vol. 49, no. 10, pp. 1147-1157, 2012.

[11] P. An, A. Zhang, Y. Xing, B. Zhang, W. Ni, and W. Ren, "Experimental study on settling characteristics of thick selfweight collapsible loess in Xinjiang Ili region in China using field immersion test," Soils and Foundations, vol. 58, no. 6, pp. 1476-1491, 2018.

[12] H. Xing and L. Liu, "Field tests on influencing factors of negative skin friction for pile foundations in collapsible loess regions," International Journal of Civil Engineering, vol. 16, no. 10, pp. 1413-1422, 2018.

[13] C. J. Lai, Y. P. Zhu, and N. Guo, "Water immersion deformation of unsaturated and compacted loess," Soil Mechanics and Foundation Engineering, vol. 57, pp. 110-116, 2020.

[14] D. F. Zhang, C. L. Chen, J. Yang, J. F. Wang, and W. B. Zhang, "Deformation and water retention behaviour of collapsible loess during wetting under lateral confinement," Chinese Journal of Rock Mechanics and Engineering, vol. 35, no. 3, pp. 604-612, 2016.

[15] X. F. Meng, H. J. Liao, and J. W. Zhang, "Infiltration law of water in undisturbed loess and backfill," Water, vol. 12, pp. 2388-2389, 2020.

[16] Y. A. Bagdasarov, I. G. Rabinovich, L. O. Epaneshnikov, and N. A. Khanzhin, "Compaction of collapsible soils by soaking with tamping during the collapse process," Soil Mechanics and Foundation Engineering, vol. 28, no. 4, pp. 159-164, 1991.

[17] G. El Mountassir, M. Sánchez, and E. Romero, “An experimental study on the compaction and collapsible behaviour of a flood defence embankment fill," Engineering Geology, vol. 179, pp. 132-145, 2014.

[18] S. J. Feng, Z. M. Shi, Y. Shen, and L. C. Li, "Elimination of loess collapsibility with application to construction and demolition waste during dynamic compaction," Environmental Earth Sciences, vol. 73, no. 9, pp. 1-16, 2015.

[19] X. F. Huang, Z. H. Chen, S. Ha et al., "Large area field immersion tests characteristics of deformation of self weight collapse loess under overburden pressure," Chines Journal Geotechnical Engineering, vol. 28, no. 3, pp. 382-389, 2006.

[20] A. F. Zaborotnii, "Construction of tall buildings on loess soils, using controlled soaking," Soil Mechanics and Foundation Engineering, vol. 24, no. 2, pp. 50-54, 1987.

[21] Z. C. Wang, Y. L. Xie, J. L. Qiu, Y. W. Zhang, and H. B. Fan, "Field experiment on soaking characteristics of collapsible loess," Advances in Materials Science and Engineering, vol. 2017, Article ID 6213871, 17 pages, 2017.

[22] A. Lloret, M. V. Villar, M. Sánchez, A. Gens, X. Pintado, and E. E. Alonso, "Mechanical behaviour of heavily compacted bentonite under high suction changes," Géotechnique, vol. 53, no. 1, pp. 2-40, 2003.

[23] X. F. Luo, Y. Y. Wang, and G. H. Cui, "Study on immersion test and settlement deformation of large thickness collapsible loess subgrade," Journal Lan Zhou Jiao Tong University, vol. 33, no. 1, pp. 124-130, 2014, in Chinese.

[24] H. Xing and L. Liu, "Field tests on influencing factors of negative skin friction for pile foundations in collapsible loess regions," International Journal of Civil Engineering, vol. 16, no. 10, pp. 1413-1422, 2018.

[25] Z. Liu, F. Y. Liu, F. L. Ma et al., "Collapsibility, composition, and microstructure of a loess in China," Canadian Geotechnical Journal, vol. 53, no. 4, pp. 673-686, 2015.

[26] J. Wang, D. Zhang, C. Chen, and S. Wang, "Measurement and modelling of stress-dependent water permeability of 
collapsible loess in China," Engineering Geology, vol. 266, no. 5, Article ID 105393, 2020.

[27] J.-D. Wang, P. Li, Y. Ma, S. K. Vanapalli, and X.-G. Wang, "Change in pore-size distribution of collapsible loess due to loading and inundating," Acta Geotechnica, vol. 15, no. 5, pp. 1081-1094, 2020.

[28] J. Wang, D. Zhang, N. Wang, and T. Gu, "Mechanisms of wetting-induced loess slope failures," Landslides, vol. 16, no. 5, pp. 937-953, 2019.

[29] Z. X. Yuan and L. M. Wang, "Collapsibility and seismic settlement of loess," Engineering Geology, vol. 105, no. 1-2, pp. 119-123, 2009.

[30] E. Derbyshire, T. A. Dijkstra, I. J. Smalley, and Y. Li, "Failure mechanisms in loess and the effects of moisture content changes on remoulded strength," Quaternary International, vol. 24, pp. 5-15, C, 1994.

[31] Y. M. Reznik, "Influence of physical properties on deformation characteristics of collapsible soils," Engineering Geology, vol. 92, no. 1-2, pp. 27-37, 2007.

[32] Z. Liu, F. Liu, F. Ma et al., "Collapsibility, composition, and microstructure of loess in China," Canadian Geotechnical Journal, vol. 53, no. 4, pp. 673-686, 2016.

[33] J. Lai, F. Niu, K. Wang et al., "Dynamic effect of metro-induced vibration on the rammed earth base of the bell tower," Springer Plus, vol. 5, no. 1, p. 935, 2016.

[34] R. Tadepalli, H. Rahardjo, and D. G. Fredlund, "Measurements of matric suction and volume changes during inundation of collapsible soil," Geotechnical Testing Journal, vol. 15, no. 2, pp. 115-122, 1992.

[35] S. K. Vanapalli, D. G. Fredlund, D. E. Pufahl, and A. W. Clifton, "Model for the prediction of shear strength with respect to soil suction," Canadian Geotechnical Journal, vol. 33, no. 3, pp. 379-392, 1996.

[36] P. H. Simms and E. K. Yanful, "Measurement and estimation of pore shrinkage and pore distribution in a clayey till during soil-water characteristic curve tests," Canadian Geotechnical Journal, vol. 38, no. 4, pp. 741-754, 2001.

[37] R. Bashir, J. Sharma, and H. Stefaniak, "Effect of hysteresis of soil-water characteristic curves on infiltration under different climatic conditions," Canadian Geotechnical Journal, vol. 53, no. 2, pp. 273-284, 2015.

[38] X. L. Wang, Y. P. Zhu, and X.-F. Huang, "Field tests on deformation property of self-weight collapsible loess with large thickness," International Journal of Geomechanics, vol. 14, no. 3, p. 04014001, 2014.

[39] L. Wang, X.-A. Li, L.-C. Li et al., "Characterization of the collapsible mechanisms of malan loess on the Chinese loess plateau and their effects on eroded loess landforms," Human and Ecological Risk Assessment: An International Journal, vol. 26, no. 9, pp. 2541-2566, 2020.

[40] L. Barden, A. McGown, and K. Collins, "The collapse mechanism in partly saturated soil," Engineering Geology, vol. 7, no. 1, pp. 49-60, 1973.

[41] M. He, Z. Zhang, J. Zheng, F. Chen, and N. Li, "A new perspective on the constant $\mathrm{mi}$ of the hoek-Brown failure criterion and a new model for determining the residual strength of rock," Rock Mechanics and Rock Engineering, vol. 53, no. 9, pp. 3953-3967, 2020. 